\title{
各種降圧剤投与の血清脂質に及ぼす影響*
}

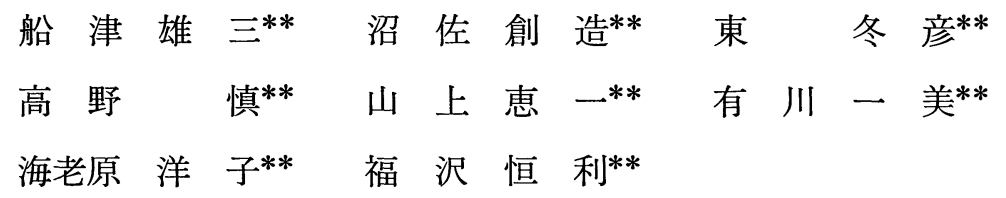

最近降圧纱の投与による血清脂質に及ぼす影響 が種々論ぜられるようになった。この問題はきわ めて重要なことであり,特に, 血清総コレステロー ルおよび中性脂肪にはすでに報告したように季節 変動があるので，この点を考慮に入れて降圧剤投 与後の血清脂質の変動を長期間に亘って観察しな ければならないと考えられる。そこで，本態性高 血圧患者 80 例に各種降圧剤を投与し, 早朝空腹 時に採血し，血清総コレステロール (TC), 中性 脂肪 (TG), HDL-コレステロール (HDL-C), FBS, $\gamma$-GTP その他肝機能および電解質等, また同時に 全身血圧，体重を測定した. そして 3〜4 か月ごと に測定をくりかえした. 観察期間は 1〜4 年 (平均 2.7年) で観察前後の測定值の比較は同じ月または 少なくとも同じ季節に測定した值を比較検討した。

各種降圧剤の種類は Table 1 に示すとおりであ り，対照群として降圧剤非投与群 19 例について も同様の測定を行った. 各群についての性別, 年 齢, 観察期間, 降圧剂投与量は Table 1 に示した. 各種降圧剂投与の観察前後の全身血圧, 血清脂 質その他の変動は, 全身血圧については Alprenolol $+\alpha$-Methyl-Dopa 併用群の拡張期圧を除い てはいずれも推計学的に有意の差をもって低下し た. TC, TG, HDL-C については平均值ではいず れも推計学的には有意の変動は認められなかった.

まず TC の観察前後の変動 (平均值)をみると, Fig. 1 に示すように, Thiazide 単独投与群では $4.5 \%$ の上昇, Alprenolol $+\alpha$-Methyl-Dopa $の$ 併 用群で $4.5 \%$ の上昇を認めたが，有意の差はな

* 1983年 7 月, 第15回日本動脈硬化学会において発表 ** 東京電力病院内科
かった. 同様に TG にっいては Alprenolol+ $+\alpha-$ Methyl-Dopa 併用群で $14.8 \%$ の上昇, Thiazide $+\alpha$-Methyl-Dopa 併用群で $10.5 \%$ の上昇, $\alpha$ Methyl-Dopa 単独投与群で $5.9 \%$ の上昇を認めた が有意の差はなかった (Fig. 2 参照).

また, HDL-C については, Thiazide 単独投与 群で $5.8 \%$ の低下，Nifedipine 単独投与群では $9.9 \%$ の上昇, Nifedipine $+\alpha$-Methyl-Dopa 併用 群で 9.7\% の上昇, Diltiazem $+\alpha$-Methyl-Dopa 併用群で $8.5 \%$ の上昇を認めたが，いずれも有意 の差はなかった (Fig. 3 参照).

以上のように平均值でみると, 各種降圧剂投与 の観察前後の血清脂質の変動は推計学的には有意 の差は認められなかったが，各症例別にみると， TC 10\%，TG，HDL-C 15\% 以上の変動を示した 病例は Table 2 に示すように, Thiazide 単独投与 群では TC の上昇 2 例 $(13.3 \%)$, HDL-C の低下 3 例 $(20 \%)$ で， $\alpha$-Methyl-Dopa 単独投与群では TG $の$ 上昇 5 例 $(26.3 \%)$ で, Nifedipine 単独投与 群では HDL-C の上昇 3 例 $(30 \%)$ となっており, 併用群についても同様の傾向が認められた.

まとめ：本態性高血圧患者 80 名に各種降圧剂 を $1 \sim 4$ 年 (平均 2.7 年) にわたり投与し，早朝空 腹時に採血し，血清総コレステロール (TC), 中 性脂肪 (TG), HDL-コレステロール (HDL-C) そ の他を測定した．観察前後で同じ月または少なく とも同じ季節に測定した值を比較検討し，次のよ うな結果が得られた。

1）各種降圧剤投与による TC, TG, HDL-C の 変化は平均值ではいずれも有意の差は認められな かった。 
動脈硬化 Vol. 12 No. 2 June 1984

Table 1 各種降圧剤投与症例その他

\begin{tabular}{|c|c|c|c|c|c|}
\hline & 湖数 & 性 & 年 令 & 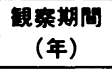 & 投与青 \\
\hline Thiazide & 15 & $\begin{array}{l}\hat{8} 5 \\
+10\end{array}$ & $\begin{array}{c}59.8 \pm 8.6 \\
(52 \sim 72)\end{array}$ & $\begin{array}{c}2.7 \pm 0.9 \\
(1 \sim 4)\end{array}$ & $\begin{array}{c}1.4 \text { 管 } \\
(1 \sim 2 \text { 食 })\end{array}$ \\
\hline$a$-Methyl-Dopa & 19 & $\begin{array}{l}\hat{8} 12 \\
+7 \\
\end{array}$ & $\begin{array}{l}61.0 \pm 8.8 \\
(52 \sim 78)\end{array}$ & $\begin{array}{c}2.7 \pm 0.8 \\
(1 \sim 4)\end{array}$ & $\begin{array}{c}675 \mathrm{mg} \\
(250 \sim 750 \mathrm{mg}) \\
\end{array}$ \\
\hline Nifedipine & 10 & $\begin{array}{l}\hat{8} 8 \\
+2\end{array}$ & $\begin{array}{c}63.5 \pm 9.7 \\
(46 \sim 79)\end{array}$ & $\begin{array}{c}2.7 \pm 1.0 \\
(1 \sim 4)\end{array}$ & $\begin{array}{c}28 \mathrm{mg} \\
(10 \sim 30 \mathrm{mg})\end{array}$ \\
\hline Diltiazem & 5 & $\begin{array}{l}154 \\
+1 \\
\end{array}$ & $\begin{array}{c}60.5 \pm 4.0 \\
(58 \sim 69) \\
\end{array}$ & \begin{tabular}{|c|}
$3.5 \pm 0.8$ \\
$(2 \sim 4)$ \\
\end{tabular} & $\begin{array}{c}108 \mathrm{mg} \\
(90 \sim 120 \mathrm{mg}) \\
\end{array}$ \\
\hline Alprenolol & 6 & $\begin{array}{l}\hat{8} 3 \\
+3\end{array}$ & $\begin{array}{c}63.5 \pm 11.1 \\
(47 \sim 75) \\
\end{array}$ & \begin{tabular}{|c|}
$3.1 \pm 1.0$ \\
$(1 \sim 4)$ \\
\end{tabular} & $\begin{array}{c}105 \mathrm{mg} \\
(75 \sim 150 \mathrm{mg}) \\
\end{array}$ \\
\hline $\begin{array}{l}\text { Thiazide+ } \\
\alpha \cdot \text { Methyl-Dopa }\end{array}$ & 5 & $\begin{array}{r}153 \\
+2 \\
\end{array}$ & $\begin{array}{c}64.5 \pm 9.3 \\
(54 \sim 79) \\
\end{array}$ & \begin{tabular}{|c|}
$3.5 \pm 0.6$ \\
$(2 \sim 4)$ \\
\end{tabular} & $\begin{array}{l}\text { T. } 1.4 \mathrm{O} \\
\text { A. } 700 \mathrm{mg} \\
\end{array}$ \\
\hline $\begin{array}{l}\text { Nifedipine + } \\
\text { a.Methyl-Dopa }\end{array}$ & 7 & $\begin{array}{l}155 \\
+2 \\
\end{array}$ & $\begin{array}{c}58.2 \pm 8.6 \\
(49 \sim 79) \\
\end{array}$ & \begin{tabular}{|c|}
$2.2 \pm 0.9$ \\
$(1 \sim 3)$ \\
\end{tabular} & $\begin{array}{l}\text { N. } \quad 25 \mathrm{mg} \\
\text { A. } 678 \mathrm{mg} \\
\end{array}$ \\
\hline $\begin{array}{l}\text { Diltiazem + } \\
\alpha \cdot \text { Methyl-Dopa }\end{array}$ & 7 & $\begin{array}{l}156 \\
+1\end{array}$ & $\begin{array}{c}63.9 \pm 5.9 \\
(54 \sim 71) \\
\end{array}$ & \begin{tabular}{|c|}
$2.9 \pm 1.2$ \\
$(1 \sim 4)$ \\
\end{tabular} & $\begin{array}{l}\text { D. } 115 \mathrm{mg} \\
\text { A. } 535 \mathrm{mg} \\
\end{array}$ \\
\hline $\begin{array}{l}\text { Alprenolol+ } \\
a \text {-Methyl-Dopa }\end{array}$ & 6 & $\begin{array}{l}152 \\
+44 \\
\end{array}$ & $\begin{array}{c}55.9 \pm 3.8 \\
(53 \sim 60) \\
\end{array}$ & $\begin{array}{c}2.3 \pm 0.7 \\
(1 \sim 3) \\
\end{array}$ & $\begin{array}{l}\text { Al. } 116 \mathrm{mg} \\
\text { A. } 625 \mathrm{mg} \\
\end{array}$ \\
\hline Control & 19 & $\begin{array}{l}\hat{8} 16 \\
+3\end{array}$ & $\begin{array}{c}62.5 \pm 8.8 \\
(50 \sim 79)\end{array}$ & $\begin{array}{c}2.7 \pm 0.8 \\
(1 \sim 3)\end{array}$ & \\
\hline
\end{tabular}

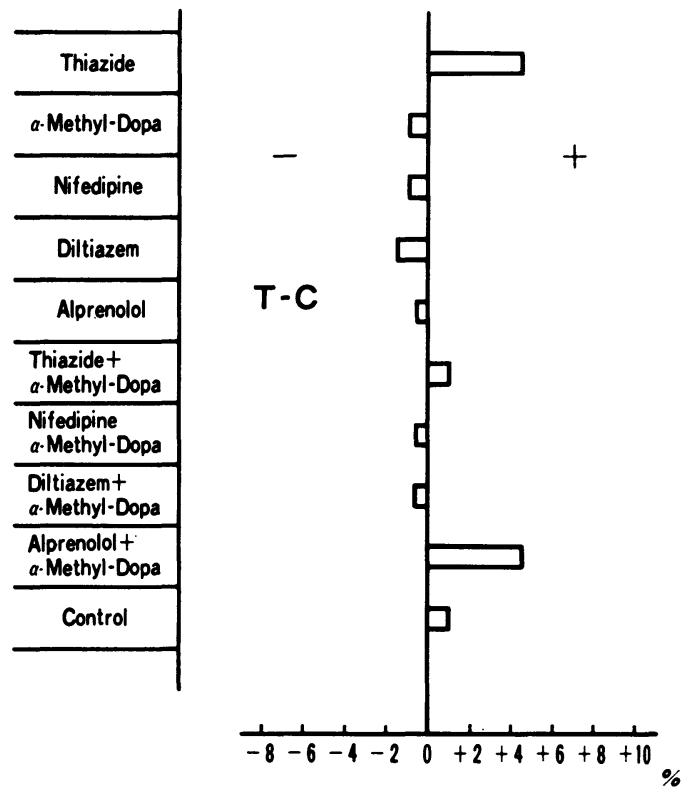

(平均值)

Fig. 1 各種降圧剤投与による血清総コレステロール值 の変動.

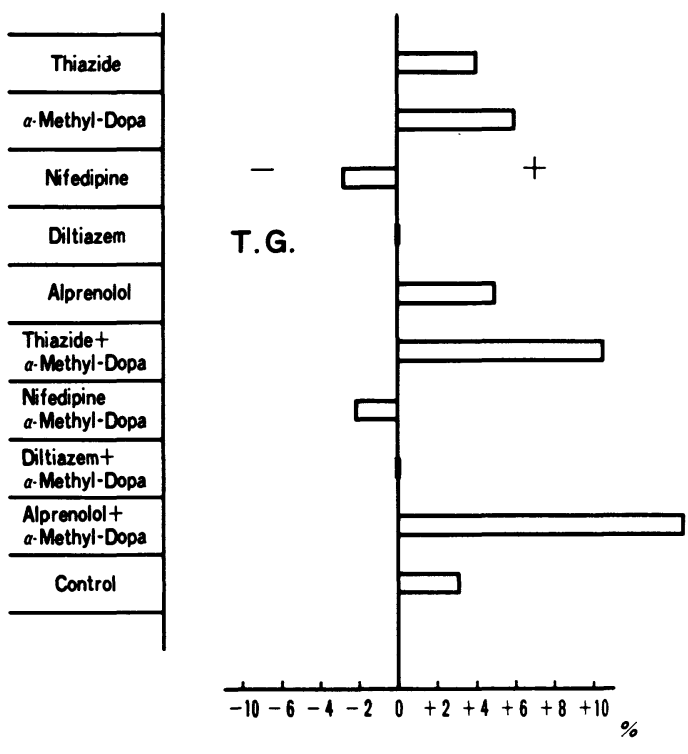

(平均值)

Fig. 2 各種降圧剤投与による中性脂肪值の変動。

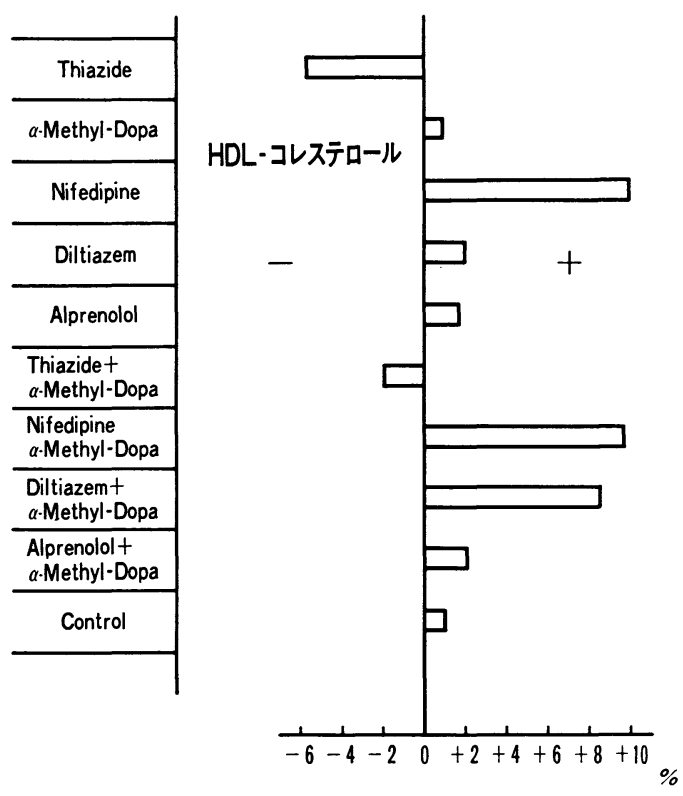

(平均値)

Fig. 3 各種降圧剤投与による HDL-コレステロール値 の変動. 
Table 2 各種降圧剤投与による血清脂質の変動

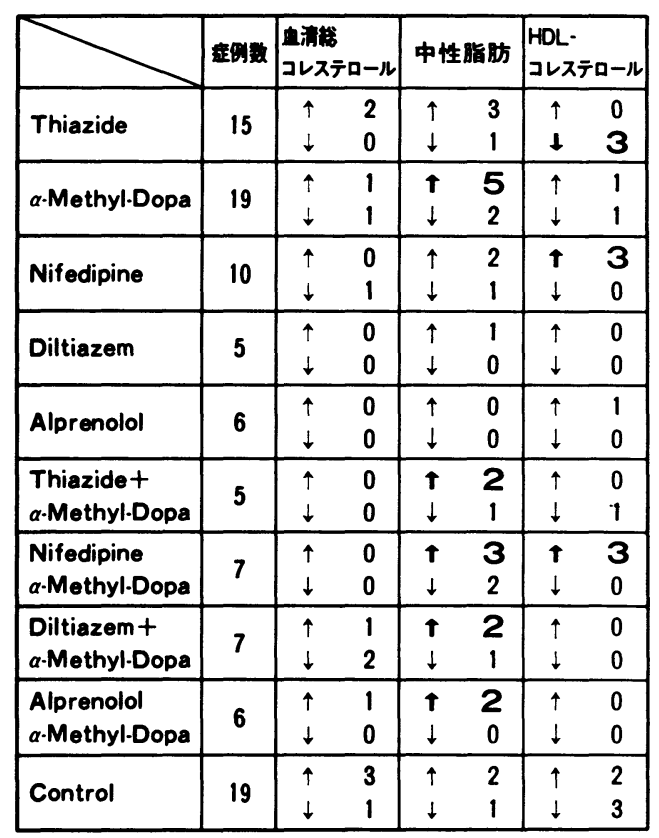

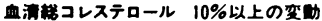

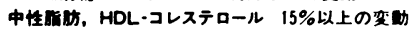

2) 各症例別にみると，Thiazide 投与群では TC が上昇し, HDL-C が低下する症例がみられ， $\alpha$-Methyl-Dopa 投与群では TG の上昇する症例が みられ，カルシウム桔抗剤投与群では HDL-C が 上昇する症例がみられた。

3）したがって，降圧剤長期投与に際しては血 清脂質の変動に留意する必要があると考えられる. 


\title{
Summary
}

\section{The Effect of Antihypertensive Drugs on Serum Lipids}

\author{
Yuzo Funazu, Sozo Numasa, Fuyuhiko Higashi, \\ Makoto Takano, Keiichi Yamagami, Kazumi Arikawa, \\ Yoko EbIHARA and Tsunetoshi FuKuZAwA
}

Department of Internal Medicine, Tokyo Denryoku Hospital, Tokyo, Japan

In order to evaluate the effect of anti-hypertensive drugs to levels of serum lipids, fasting concentration of total cholesterol (TC), triglyceride (TG) and HDL-cholesterol (HDL-C) was measured before and during therapy in 80 patients with essential hypertension. The patients were divided into 9 groups according to administrated drugs including thiazide, $\alpha$-methyl-dopa, nifedipine, diltiazem and alprenolol. Observation periods were 1 to 4 years.

No significant changes of serum TC, TG and HDL-C levels were found in all 9 groups during the study. However, patients who were treated with thiazide tend to show increased level of TC and decreased level of HDL-C. Those who were treated with nifedipine tend to show increased level of HDL-C. Patients who showed elevated serum TG were mainly found in groups of patients treated with $\alpha$-methyl-dopa.

These results suggest that it may be important to know serum lipids levels when anti-hypertensive drugs are administrated to patients for a long period of time.

Key words: antihypertensive drugs, serum lipids. 